\title{
Treatment of Industrial Water by Nano Technology
}

Kareem T. shnaihej ${ }^{*}$, Lamya J. Basri ${ }^{*}$, Hasan N. Mohesn ${ }^{*}$

\author{
Dr. Khalid A. Sukkar ${ }^{* *}$ \\ *Petroleum R\&D center
}

${ }^{* *}$ Chem. Eng. dep. /university of technology

الخلاصة

تقنية النانوتكنولوجي: تعتبر من الانجازات العلمية الحديثة حيث نوفر التقانة النانوية وهي هندسة وفن معالجة المادة على المستوى النانوي (100 -1 نانومتر)، القدرة على تصنيع مو اد نانوية جديدة تستخدم في معالجة المباه السطحية و المياه الجوفية ومياه الصرف الصناعي الملوثة بأيونات المعادن السامة و المواد العضوية والغير عضوية بالإضافة إلى الكائنات الدقيقة.

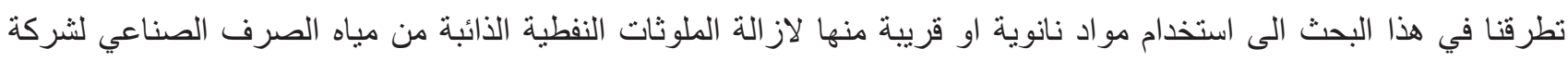
مصافي الجنوب حيث استخدمنا انابيب الكاربون النانوية المتعددة carbon Nano tubes multi wall ( ويمكن وصف وظيفة الأنابيب على أنها مصفاة جزيئات، تسمح بمرور جزيئات الماء الصغيرة و تحتجز جزيئات الملوثات الكبيرة التي يصعب عبور ها من خلال نفق الأنبوب). كذلك استخدمنا مسحوق الكاربون المنشط Activated carbon و فلاتر الكاربون القريبة من نانوية

$$
\text { الكلمات الدالة الكاربون النشط ، انابيب الكاربون النانوية المتعددة،المياه الصناعية الملوثة }
$$

\section{$\underline{\text { Abstract }}$}

Nanotechnology: - It is one of the modern scientific achievements where nanotechnology is available, namely the engineering and art of nano scale material treatment (100 nanometers.

The ability to manufacture new Nano materials used to treat surface water, groundwater and industrial wastewater contaminated with toxic metal ions, organic and inorganic substances as well as microorganisms.

In this research, we discussed the use of Nano materials, or nearby, to remove the dissolved oil pollutants from the industrial wastewater of the South Refinery Company, where we used multitubes of carbon nanotubes. The function of the tubes can be described as a particle filter, Hold large particles of contaminants that are difficult to pass through the tube tunnel). We also used activated carbon powder and carbon filters near pore nanoparticles

Keyword activated carbon, carbon Nano tubes multi, industrial waste water

\section{Introduction:}

With the increasing speed of human growth in the industrial and technological sectors that require more sources of energy source the problems of environmental pollution as a result of the receipt of 
waste in all forms leading to the disaster of chemical pollution where the difficulties and complications of the elimination of pollutants or more directly to reduce the situation where scientists are unable to act. Optimizing the design and treatment of materials at the nanotechnology level provides a great opportunity for scientists to develop strategies to protect the environment from pollution, produce clean energy sources, optimize energy use, solve water pollution and other environmental problems.

\section{The theoretical part:}

\section{The concept of nanotechnology:}

The concept of nanotechnology is based on the fact that particles of less than 100 nanometers (nanometers, a thousandth of a millionth of a meter) give material in which new properties and behaviors are introduced.

This is because these particles (which are smaller than the characteristic lengths associated with certain phenomena) exhibit new physical and chemical concepts, leading to new behavior based on particle size. For example, the electronic structure, conductivity, efficiency, melting point, and mechanical properties of the material are all changed when the particle size is less than a critical value of size (8).

\section{Hydrocarbon Substances:}

Hydrocarbons form the largest percentage of pollutants present in wastewater from petroleum industries. Some other compounds are added: sulfonic acid, sulfuric compounds, and sodium salts.

1) Extremely high polarity compounds: organic acids are very high polarity compounds because they contain one or more polar carboxyl groups (each carboxyl group can form two hydrogen bonds with a carboxylic group of a nearby molecule).

2) High polarity compounds: such as alcohols Because they contain one or more polar hydroxyl $(\mathrm{OH})$ groups, each hydroxyl group can form one hydrogenate with a hydroxyl group of a neighboring molecule

3) Polar compounds: such as esters, aldehydes, and ketones For carbon atom bonding with oxygen atoms with high electrolysis, aldehydes can form hydrogen bonds to bind the carbonyl group to hydrogen atoms so that the aldehyde grades are higher than those of ketones

4) weak polycarbonate compounds such as primary and secondary amines because they are monoclonal compounds containing $\mathrm{H}$ that are linked to $\mathrm{N}$ other than thiocyclic acid, which enables them to make hydrogen bonds between them (nitrogen is less electrolytic than oxygen) and is 
therefore followed by aldehydes and ketones in terms of elevation in boiling points .

5) Very weak polarity compounds: Ethers are weak polycrystalline compounds, so they follow the primary and secondary amines in terms of high boiling points. The triglycerides are less polar than the ethers because the N-C is less than the O-C.

6) Non-polarity compounds: such as alkyl halide, interferon canals and branching kernels (9).

\section{Objective of the research}

Disposal of hydrocarbons in industrial water to preserve the environment and try to utilize, recycling and use treated water.

\section{Materials and equipment used}

\section{Materials used:}

1 - Activated carbon activated and soft activated carbon

2. Carbon Nano tube multi wall (CNTM) Sand

4. Glass granules Bromocresol green

6. Ethanol

7- Engine oil motor

\section{Equipments:}

1- Steel stile length $25 \mathrm{~cm}$, inner diameter $22 \mathrm{~mm}$ and outer diameter $25 \mathrm{~mm}$ in order to contain carbon nanotubes

2- $25 \mathrm{~cm}$ plastic column, $22 \mathrm{~mm}$ inner diameter and $25 \mathrm{~mm}$ outer diameter for sand filter work

3 - Regulating the flow of air at a different speed of flow in order to control the process of drilling.

4 - Plastic tubing manufactured locally for the process of drilling

5 - Different glass containers

6- An electric motor to pump air

7- Electric water pump

8- Fluid flow velocity

9 - A bottle of nitrogen with purity $99 \%$

10 - Plastic pipes with different diameters

11- Copper pipes

12 - Rolls and blankets

13- Stainless Steel Clip

14 - Glass wool 


\section{(JPR\&S)}

15- Metal and plastic connections with different measurements

16- Heaters with different capacities

\section{machines used}

1. X-Ray diffract meter (XRD)

This device is used to diagnose the solid properties of solids only and is not used to examine liquids, wet materials and Figure (1) shows the shape of the device.

2. Particle size

This device is used to determine the size of the minutes with detection limits up to the nanometer and Figure (2) shows the shape of the device.

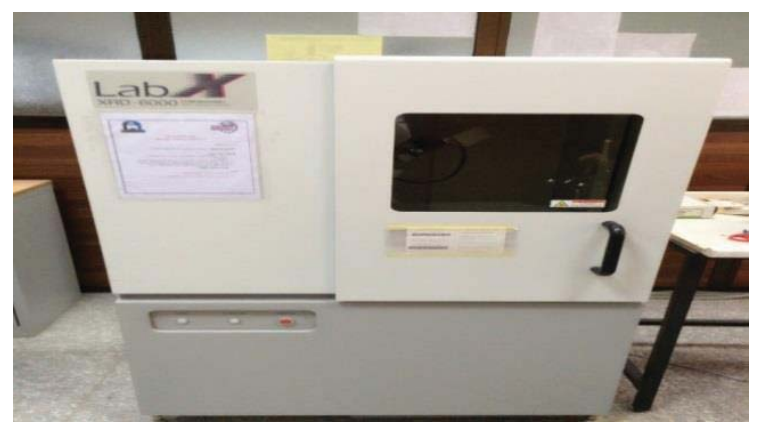

Fig. (1) Shows the X-Ray diffract meter

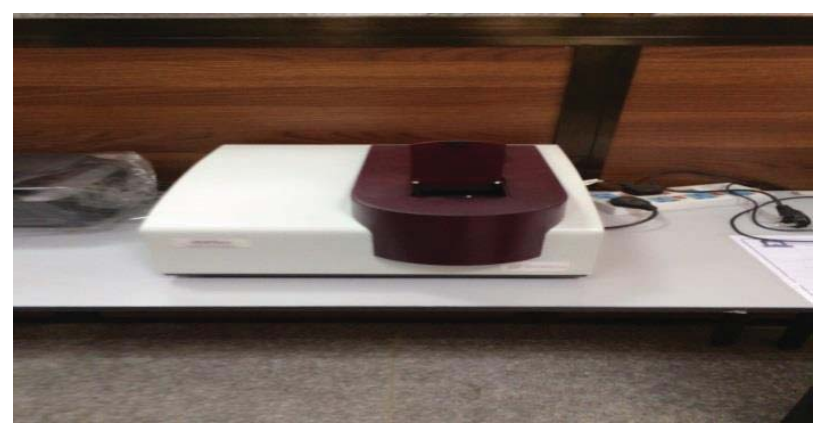

Fig. (2) Shows Particle size

3. Total organic compound (TOC)

The device is used to check the ratio of hydrocarbons (TOC) and Figure (3) shows the shape of the device.

4- Scanner Microscope (SEM), Figure (4) shows the shape of the device

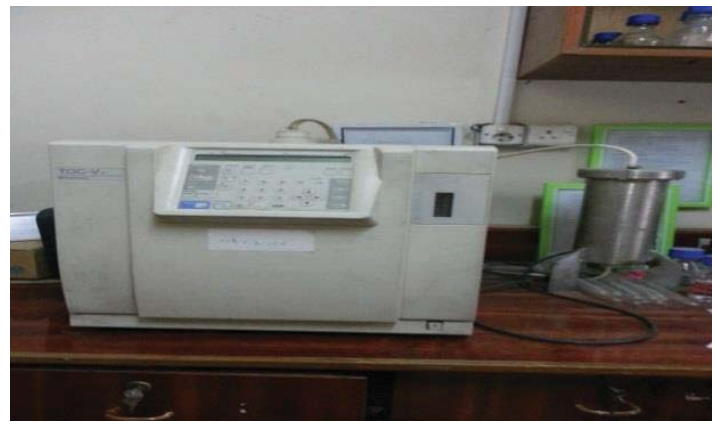

Fig. (3) Shows the TOC device

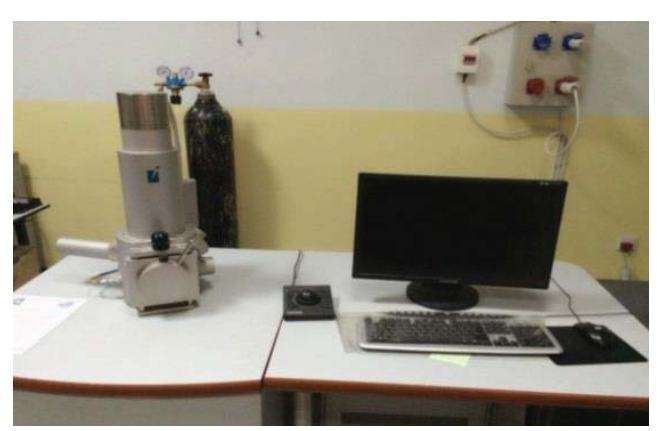

Fig. (4) Shows the scanner electron microscope (SEM)

5) Fourier Transform Infrared Spectroscopy (FTIR) As shown in Figure (5).

6) UV-VIS spectro photometer Figure (6) shows the shape of the device. 


\section{No.19}

Journal of Petroleum Research \& Studies

(JPR\&S)

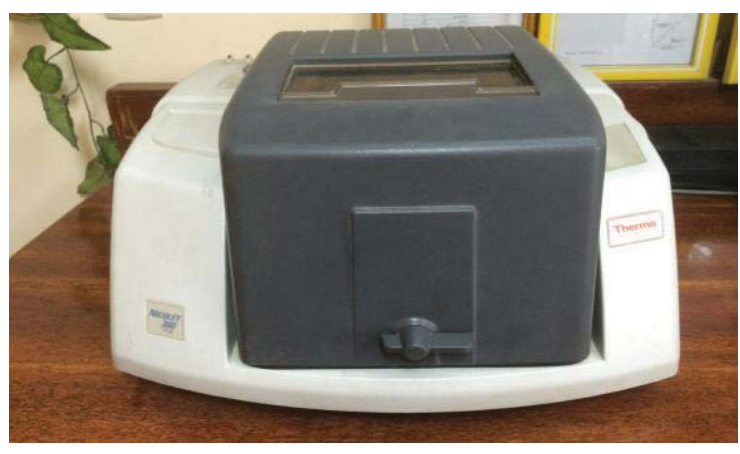

Fig. (5) Device (FTIR)

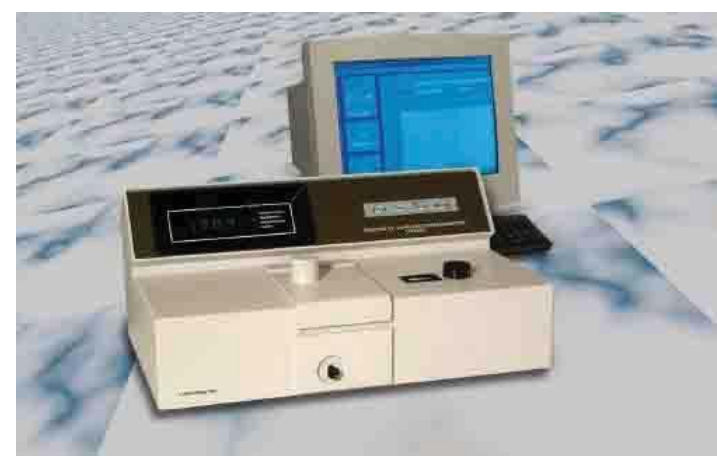

Fig. (6) Shows the UV-VIS

\section{Experimental}

The work has been done in two parts, as described below

1) Part I:

A preliminary laboratory system was developed to investigate the effectiveness of activated charcoal on the removal of organic materials for laboratory-prepared water samples, which are a mixture of normal water, oily, engine oil, dissolved bromo crystalline dye, and ethanol alcohol.

Where a local flow system has been brought available in the local markets and converted to a system consisting of three filters linked to each other and linked by an electric developer to withdraw water and the filters are manufactured as follows:

The filter contains Sand (Sand) where the sand is placed in a plastic container and sealed with a cotton piece on both sides. The table (1) shows the results obtained from the analysis) Sieving analysis by particle size) for sand used. Then put the filter inside the system so that the flow of fluids and enter from the bottom of the filter and graduated from the top and shape (7)

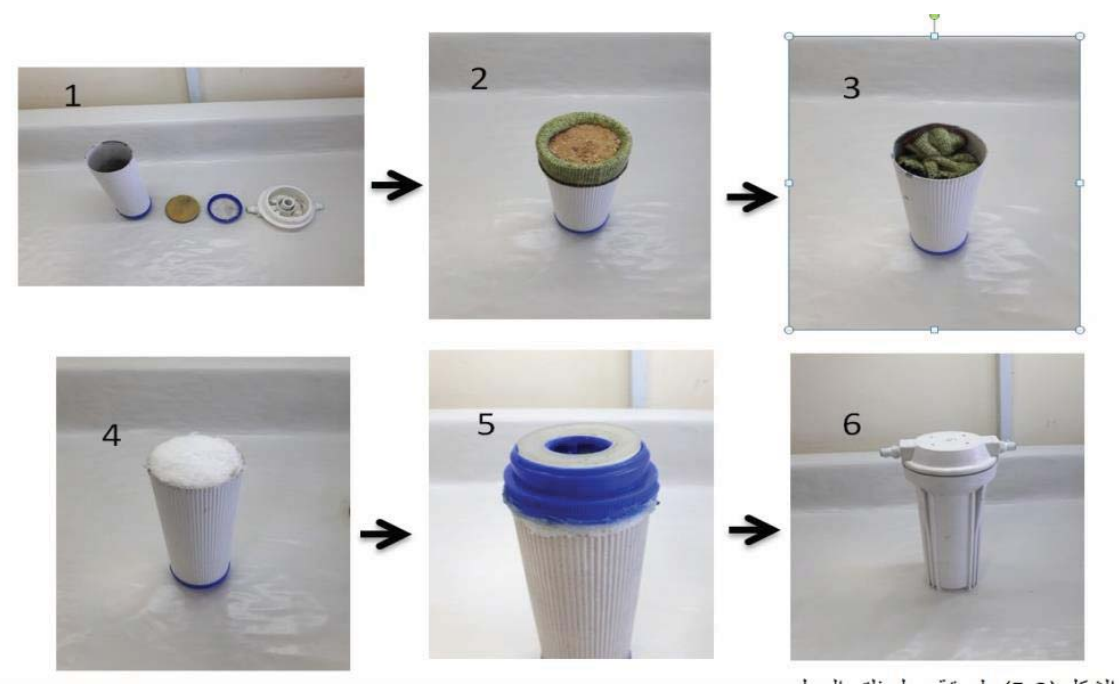

Fig. (7) Method of working sand filter 
Table (1) Results obtained from analysis by sieving analysis Particle size for sand used

\begin{tabular}{|c|c|c|}
\hline No & Particle size(mm) & Weight(gm) \\
\hline \hline 1 & 1.18 & 14.6105 \\
\hline \hline 2 & 0.6 & 31 \\
\hline \hline 3 & 0.3 & 159.961 \\
\hline
\end{tabular}

The second filter contains the coarse activated charcoal in the form of a cylinder and a series of tests are carried out in the third chapter. It is placed in the system so that the fluid enters the outer wall to the inner wall and the shape (8) shows the shape of the filter.The third filter contains activated carbon packed in a plastic container and closed with a piece of cotton on both sides. A group of tests were carried out at the Technological University of the Nanotechnology Department, as explained in Chapter 3 and Figure (9), which explains how the filter works.
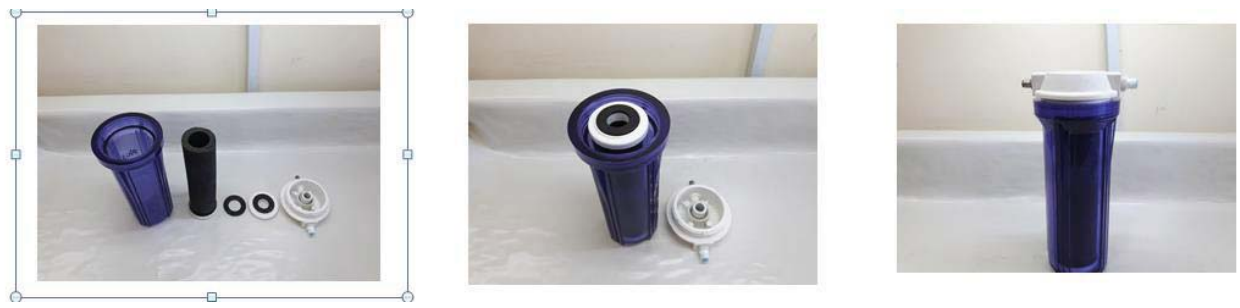

Fig. (8) Shows how the second filter (compressed activated charcoal)

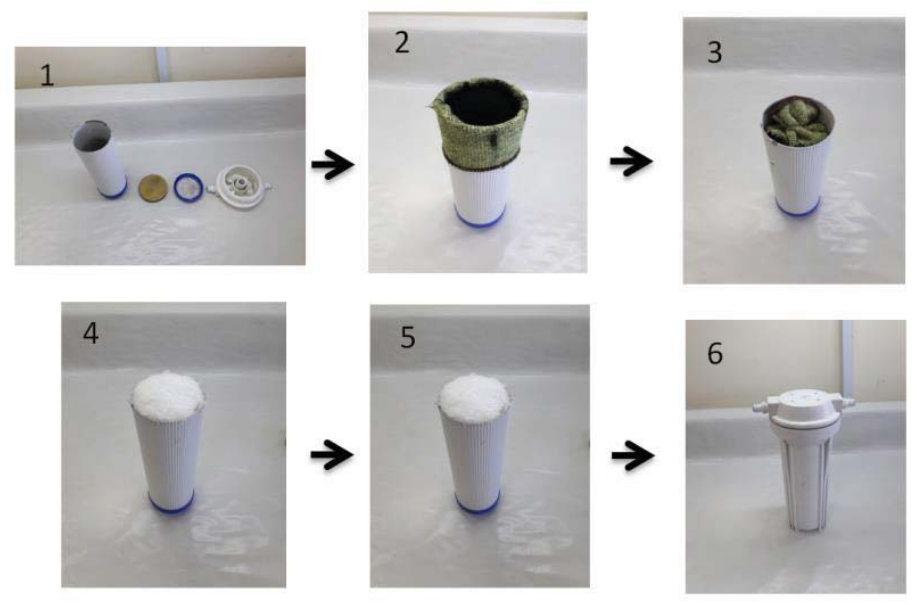

Fig. (9) How the soft activated carbon filter works

The filters were connected together and connected with a pull system consisting of a glass container and an electric pull-out model. Figure (10) shows the shape of the initial system.

The first filter works to clear the water from the clay and the other suspended materials. The 
second filter works to rid the water of the particles with the smaller molecular sizes and the suspended fatty materials. The third filter works to filter the water from the dissolved organic matter such as the bromochrysol and insoluble organic matter the engine).

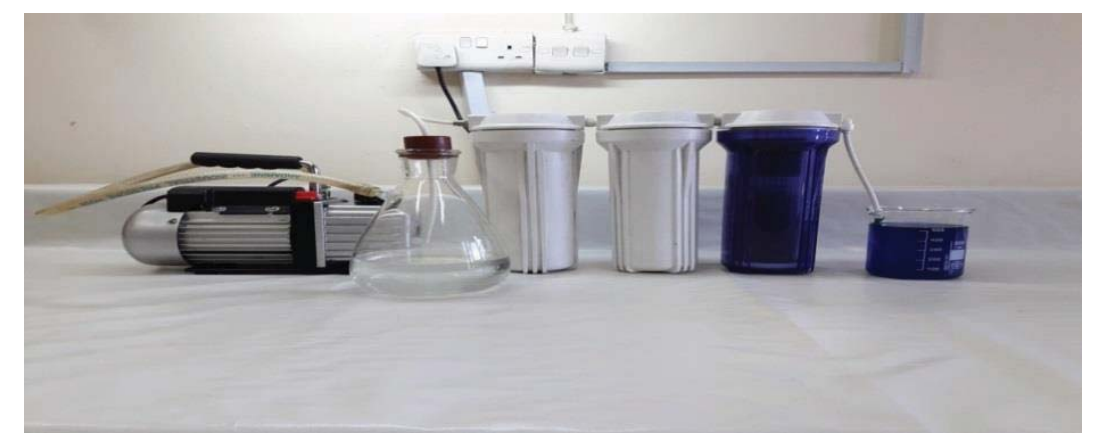

Fig. (10) Primary Separation System

The TOC test which the ratio of hydrocarbons in the model to samples of water inside and outside, and the results of the test.

TOC: - Total organic compound

\section{2) Part II}

The work of another local system and laboratory manufacturing This system consists of two parts:

section One: It consists of plastic tubs manufactured locally and prepared on the basis of physical separation in order to conduct the process of airing and skimming, where it connects with an electric motor and regulating flow to pump air and this part is used to get rid of hydrocarbons of high molecular weights not soluble in water where the separation on the basis of physical.

Section II: It consists of a pump to pump the resulting water after the cavity process and vertical separation. The first column is a $25 \mathrm{~cm}$ long plastic column with $22 \mathrm{~mm}$ diameter and $25 \mathrm{~mm}$ outer diameter sand. Sand layers are laid after separating them into three layers. The thin layer is placed with $0.3 \mathrm{~mm}$ diameters first, which is placed in the bottom of the column followed by a layer With diameters greater than $0.6 \mathrm{~mm}$ and then with a diameters of $1.18 \mathrm{~mm}$, sealed with a glass wool on both sides, so that the flow of fluid from the top of the column passes first on the coarse sand layer and exits from the bottom to go to the second column. Flow meter for regulation of water flow velocity Figure (11) shows the shape of the column. 


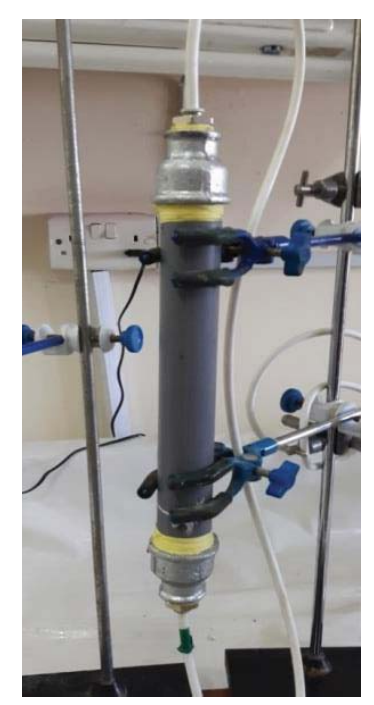

Fig. (11) Shows the sand column

The second column is a $25 \mathrm{~cm}$ steel stile, $22 \mathrm{~mm}$ diameter and $25 \mathrm{~mm}$ outer diameter. It contains carbon activated carbon. Activated carbon has been mixed with glass granules to facilitate the flow of water through it, placing it in the column and sealing it from top and bottom with glass wool. A piece of stainless steel buckles and connected by plastic pipes with the first column on the one hand and on the other hand connects with a source of hot nitrogen gas by copper pipes and three-port valves. The column is rotated with an electric filter for the purpose of heating.

The second column was filled with active carbon and several experiments were performed on it. It was then replaced with carbon nanotubes CNT. The tests were carried out on the water inside and outside the system using active carbon and CNT.

The first and second sections are connected to each other respectively, where the resulting water is taken after the skimming process and driven by a water pump to the second section to get rid of the rest of the organic contaminants. Figure (12) shows the scheme of the system design. Figure (13). 


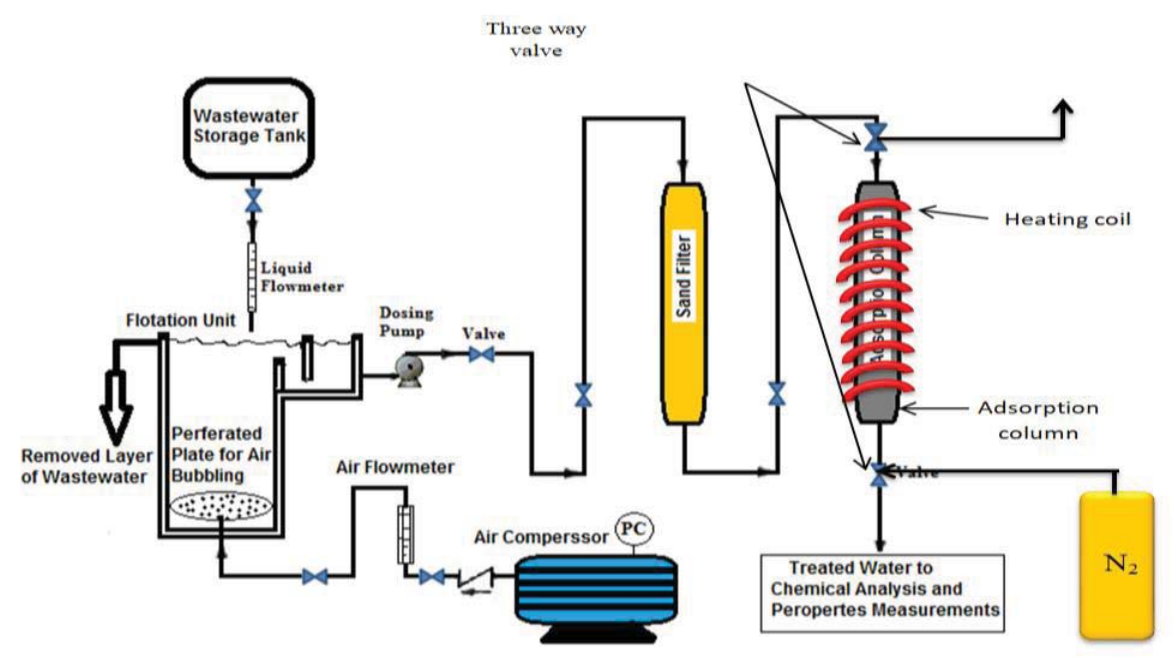

Fig. (12) Design scheme of the system

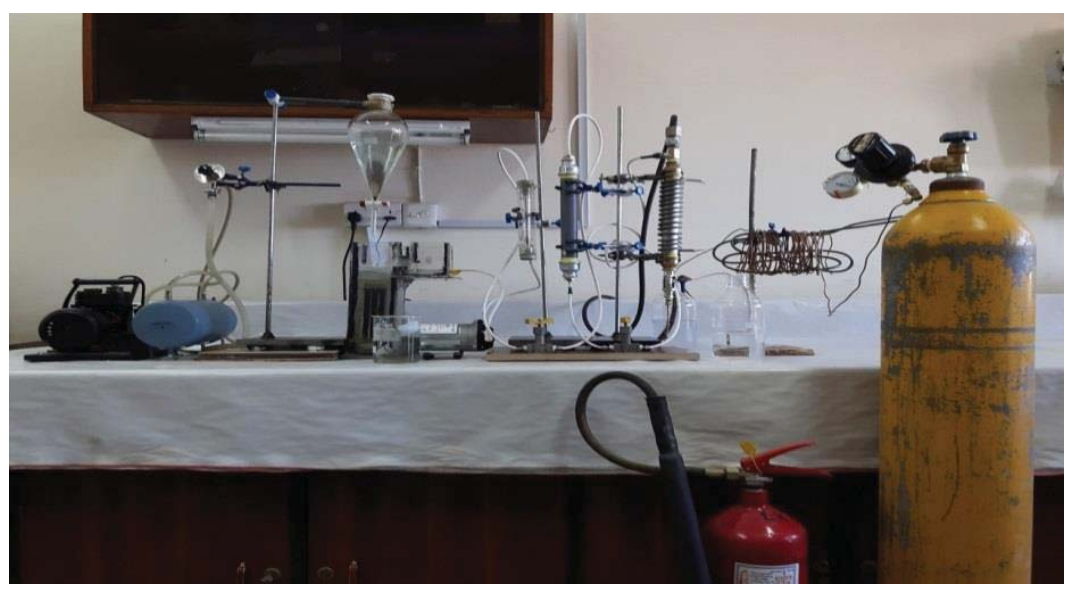

Fig. (13) Shows the image of the system

\section{Result and discussion}

\section{Active charcoal capacity to remove organic compounds}

The first steps of the work were accomplished by using the raw system and the active and coarse active carbon material to determine the active charcoal capacity to remove the organic pollutants. Several tests were conducted to determine the specifications of the active and coarse active carbon used.

\section{Particle size}

Sample of the Activated Carbon Activated Particle Model was examined by Particle size the purpose of the test to determine the size of the minutes and the figure (14) shows a diagram of the activated carbon model in Partical size. 


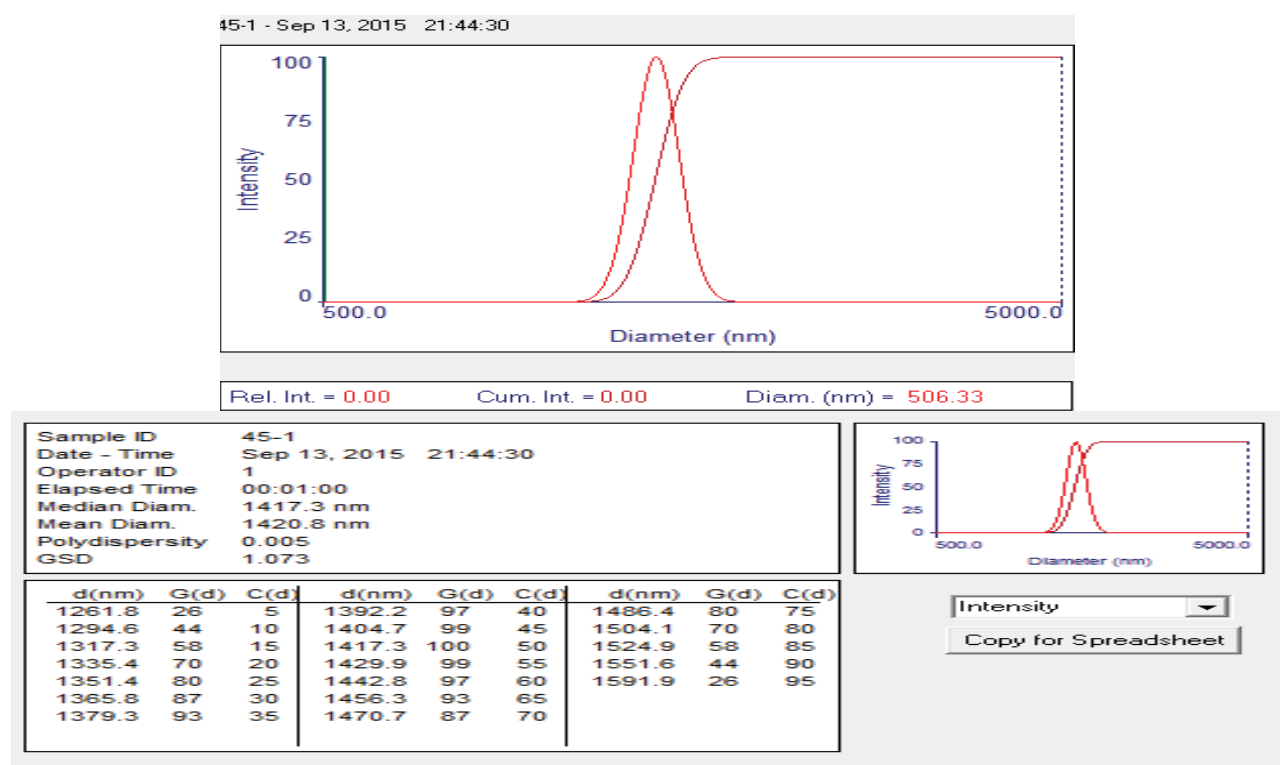

Fig. (14) Shows a diagram of the model activated carbon particle size

\section{$\underline{\text { SEM examination }}$}

The soft activated carbon was examined with a scanning electron microscope (SEM). The purpose of this examination is to know the surface structure of the sample, figure (15) in (A, B \& C) showed a sample of carbon activated with different dimensions $(10 \mu \mathrm{m}, 5 \mu \mathrm{m}, 2 \mu \mathrm{m})$ Respectively.

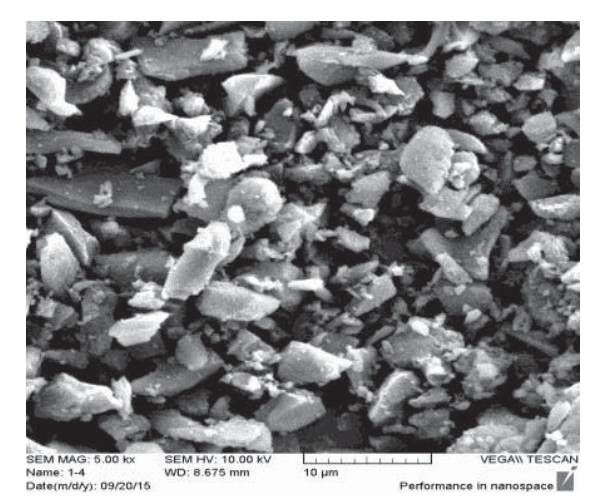

Fig. (15A) Shows the activated carbon image of the electron microscopy microscope and after it $10 \mu \mathrm{m}$

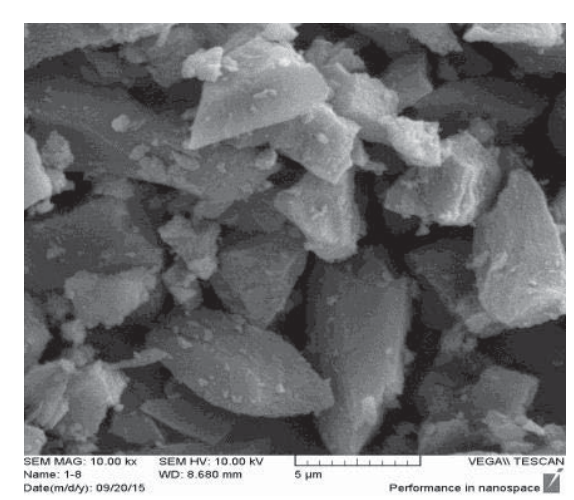

Fig. (15B) Figure shows the activated carbon image of the electron microscopy microscope and after it $5 \mu \mathrm{m}$

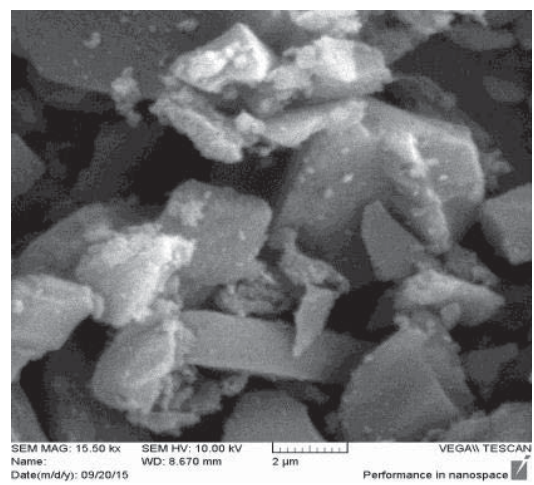

Fig. (15C) The figure shows the activated carbon image of the electron microscope and then $2 \mu \mathrm{m}$

\section{$\underline{\text { X-Ray Diffract meter }}$}

$\mathrm{X}$-Ray Diffract meter is used to diagnose the composition properties of solids only and is not used to examine liquids and wet materials. Figure (16) shows the XRD diagram of activated carbon 


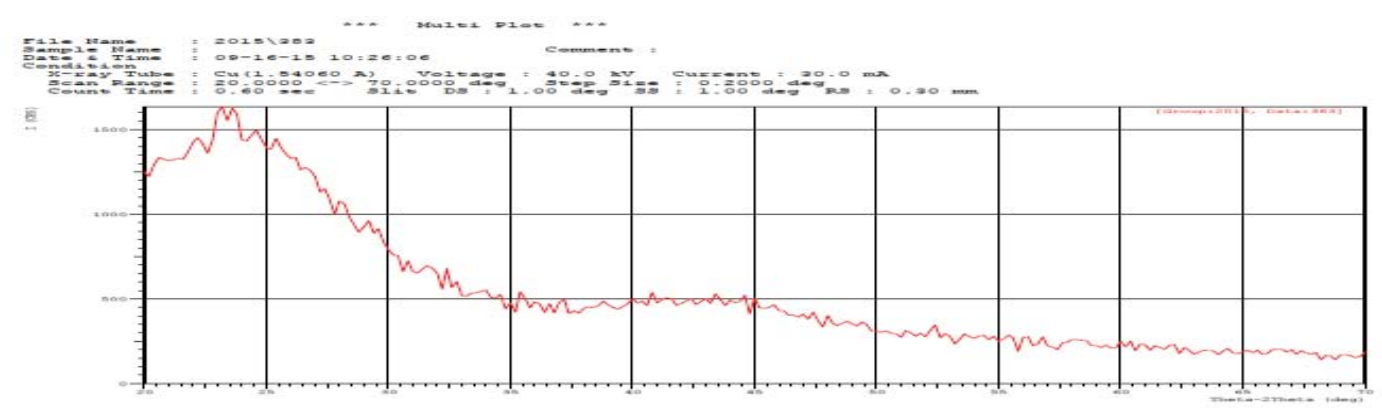

Fig. (16) Shows a sample of activated activated carbon by X-Ray diffract meter

\section{FTIR examination}

The FTIR test was conducted to determine the active aggregates present in a model of activated carbon and Figure (17) shows the FTIR chart for active carbon, and Table (2) shows the results of a series of other tests conducted on soft activated carbon.

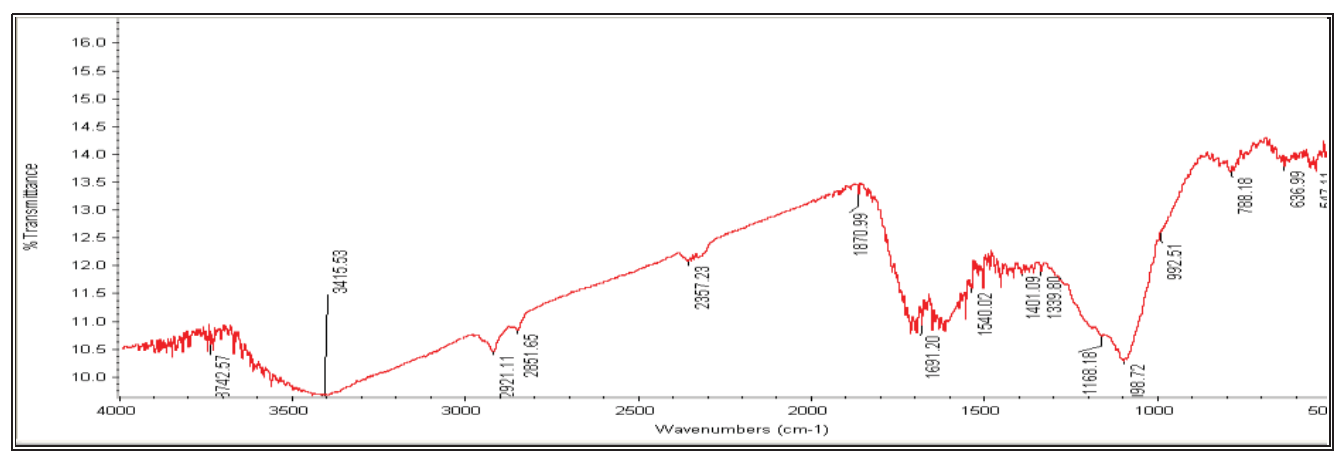

Fig. (17) FTIR scheme for active carbon

Table (2) Results of tests conducted on soft activated carbon (Bauder)

\begin{tabular}{|c|c|c|}
\hline NO & TEST & Activated carbon \\
\hline \hline 1 & Surface $\operatorname{area}\left(\mathrm{m}^{2} / \mathrm{gm}\right)$ & 1130.4436 \\
\hline \hline 2 & Pore Volume $\left(\mathrm{cm}^{3} / \mathrm{gm}\right)$ & 0.9505 \\
\hline 3 & Pore size $\left({ }^{\mathrm{O}} \mathrm{A}\right)$ & 35.1775 \\
\hline
\end{tabular}

A number of tests were carried out for the active carbon-compressed material in the form of a cylinder used in the first steps and Table (3) shows these tests. 
Table (3) Results of tests conducted on coarse activated charcoal

\begin{tabular}{|c||c|c|}
\hline NO & TEST & Activated carbon \\
\hline \hline 1 & Surface $\operatorname{area}\left(\mathrm{m}^{2} / \mathrm{gm}\right)$ & 765.7083 \\
\hline \hline 2 & Pore Volume $\left(\mathrm{cm}^{3} / \mathrm{gm}\right)$ & 0.4712 \\
\hline \hline 3 & Pore size $\left({ }^{\mathrm{O}} \mathrm{A}\right)$ & 24.6202 \\
\hline
\end{tabular}

To find out the effectiveness of activated charcoal on the removal of organic materials for samples of water prepared laboratory, which is a mixture of ordinary water and oily and engine oil and the dye of bromocrizol dissolved and ethanol alcohol. TOC means the ratio of hydrocarbons in the model to samples of water inside and outside the system. The results of the test are shown from the system. The TOC value of water inside the system was 200 ppm. Table (4) shows the results of the TOC test The system has a different flow rate.

Table (4) Results of the TOC test for contaminated water prepared by laboratory and treated using the initial system

\begin{tabular}{|c||c||c|}
\hline \hline NO. & Flow rate $(\mathbf{m l} / \mathbf{m i n})$ & TOC $(\mathbf{p p m})$ \\
\hline \hline 1 & 5 & $4.68 \mathrm{ppm}$ \\
\hline 2 & 10 & 10.05 \\
\hline 3 & 20 & 21.09 \\
\hline \hline 4 & 30 & 27.92 \\
\hline \hline 5 & 40 & 33.62 \\
\hline
\end{tabular}

It is noted that active carbon has the ability to remove organic compounds mixed with water, whether soluble or insoluble. The highest removal rate was in low flow velocity due to the time required for the absorption process.

\section{Working on industrial water}

Several modifications were made to the initial system to improve the efficiency of active carbon to remove and study organic materials more precisely. The columns of suitable dimensions were used to calculate the exact amount of active carbon and the method of introducing fluids into the system from the clouds to the batch was replaced. The final system takes into consideration the steps of re - activation and all other variables. The work on the final system includes two parts, the part of removing the non-polar organic matter (non-soluble) by the process of drilling and skimming depending on the difference in density between water and organic matter. This part removes a large amount of organic matter from industrial water before it passes on the active carbon column.

The second part is the removal of polar organic compounds (dissolved in water) by passing on activated carbon or CNT. It has brought samples of industrial water in the South Refineries 
Company so that this water comes from more than one source. It comes from heavy water, rain water and the following water from RO units and water coming out of the ion exchanger unit. This water was only mechanically insulated so that the contaminated water reaches $(500 \mathrm{~m} 3 / \mathrm{h})$ and the proportion of salts (TDS) to 18 thousand and then go this polluted water to Khorabad Allah. Several tests were carried out on the industrial waters of the South Refineries Company. This industrial water was examined. Table (5) shows the results of tests of industrial water samples (final and after skimming and normal water). Microscopic images were taken for two models (final and after skimming), Figure (18) shows a microscopic image of the final water model and the figure (19) microscopic image of water model after skimming

Table (5) Shows the results of industrial water tests for South Refineries Company

\begin{tabular}{|c|c|c|c|c|}
\hline Material & المسندات اليبأبية & 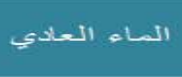 & بعد القثشط & 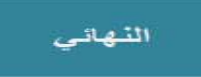 \\
\hline Turbidity & $25 \mathrm{NTU}$ & Nil & NTU 12.5 & $11.78 \mathrm{NTU}$ \\
\hline $\mathbf{P H}$ & $8.5-6.5$ & 7.55 & 7.28 & 7.31 \\
\hline T.D.S ppm & Max 1500 ppm & 443.42 & 5645 & 6163.3 \\
\hline TSS ppm & Max 40 ppm & 2 & 23.6 & 18.8 \\
\hline TOC ppm & 1-3 ppm & - & 18.87 & 13.27 \\
\hline $\begin{array}{l}\text { Total Alkalinity } \\
\text { ppm }\end{array}$ & 30-500 ppm & & 1.7 & 2 \\
\hline Conductivity $\mu \mathrm{s} / \mathrm{CM}$ & - & 642 & 9830 & 1190 \\
\hline $\mathrm{Cl}^{-}(\mathrm{ppm})$ & Max 250 ppm & 53.1 & 1008.9 & 1000.05 \\
\hline $\mathrm{SO}_{4}^{-}(\mathrm{ppm})$ & Max 400 ppm & 81.41 & 1673.9 & 1402.3 \\
\hline $\mathrm{Na}^{+}(\mathrm{ppm})$ & - & - & 483.7 & 566.4 \\
\hline $\mathrm{K}^{+}(\mathrm{ppm})$ & - & - & 17 & 21.9 \\
\hline $\mathrm{Fe}(\mathrm{ppm})$ & Max 2.0 ppm & Nil & 0.02 & 0.034 \\
\hline Ni (ppm) & Max 2.0 ppm & Nil & Nil & Nil \\
\hline Cr (ppm) & Max 0.05 ppm & Nil & Nil & Nil \\
\hline$Z_{n}(p p m)$ & Max 2.0 ppm & Nil & Nil & Nil \\
\hline Co (ppm) & - & Nil & Nil & Nil \\
\hline $\mathrm{Mg}(\mathrm{ppm})$ & (ppm) 150 & 36 & 300 & 328 \\
\hline Mn (ppm) & Max 0.05ppm & Nil & Nil & Nil \\
\hline Cu (ppm) & Max 0.2 ppm & Nil & Nil & Nil \\
\hline $\mathbf{P b}(\mathrm{ppm})$ & Max 0.1 ppm & Nil & Nil & Nil \\
\hline$V(p p m)$ & Max $2.0 \mathrm{ppm}$ & Nil & 4.32 & 2.67 \\
\hline $\mathrm{Hg} \mathbf{n g} / \mathbf{1}$ & Max 0.005 ppm & Nil & 56.2 & Nil \\
\hline COD $(\mathrm{ppm})$ & 150 ppm max as & 130 & 3 & 15 \\
\hline $\begin{array}{c}\text { Hydrogen sulifide, } \\
\mathrm{S}^{-2} \text { (ppm) }\end{array}$ & Max 3 ppm & & 16 & 16 \\
\hline Refractive Index & - & 1.3329 & 1.3389 & 1.33390 \\
\hline $\begin{array}{c}\text { Density@ } 15.6 \\
\mathrm{~g} / \mathrm{cm}^{3}\end{array}$ & - & - & 1.00767 & 1.00468 \\
\hline SP.GR@15.6 & - & - & 1.0082 & 1.0057 \\
\hline
\end{tabular}




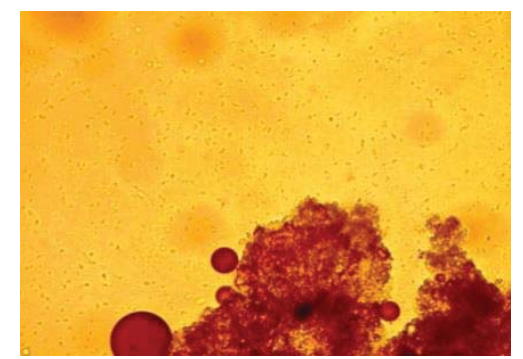

Fig. (18) Microscopic image of the final water model

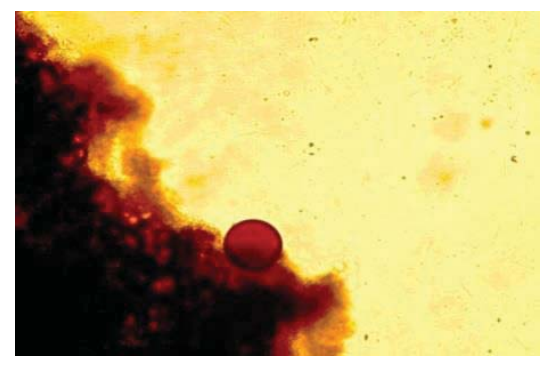

Fig. (19) Microscopic image of water model after skimming

We note from the results of water tests before the Khor Abdullah that the concentration of certain substances has exceeded the environmental determinants permitted by such a large concentration of organic materials, the concentration of sulfate, hydrogen sulfide, chloride, magnesium, as well as the proportion of dissolved salts.

\section{Treatment of industrial water using activated carbon}

The use of the final system, where the column fill material carbon activated, the most important modification or development that has been work done in order to speed up the flow through the material active carbon has been added percentages of equal-grained glass, and in this way has been to overcome the accumulation of material active carbon as a result of Flow pressure as well as eliminate dead areas that can pass through the water without prejudice to active carbon, The pass the industrial water retrieved from the South Refineries Company on the system at a constant speed (20 $\mathrm{ml} / \mathrm{min}$ ), and conducted several tests on extra water table (6) shows the results of the examination TOC on the outside water from the system for different periods of time, and the table (7) shows the results of other laboratory tests carried out on the outside water.

Table (6) Shows the results of the TOC test for water treated with activated carbon

\begin{tabular}{|c|c|c|}
\hline No & Time $(\min )$ & TOC $(\mathrm{ppm})$ \\
\hline \hline 1 & Before treatment & 13.27 \\
2 & waste & 15.63 \\
3 & After flotation & 11.63 \\
4 & 0 & 3.22 \\
5 & 15 & 3.25 \\
6 & 30 & 3.135 \\
7 & 60 & 3.857 \\
8 & 90 & 5.15 \\
9 & 120 & 5.13 \\
10 & 150 & 5.90 \\
11 & 210 & 5.85 \\
12 & 270 & 5.91 \\
\hline
\end{tabular}


From the results obtained for the TOC test, we note that the part of the system for cavitation using a stream of air and surface skimming has reduced the proportion of organic matter from $13.27 \mathrm{ppm}$ to $11.63 \mathrm{ppm}$. When water is emitted on the sand column (plankton removal), the active carbon column has reduced the concentration of organic matter To $3.2 \mathrm{ppm}$ and then increase concentration until it reaches a constant level almost after the flow of water at constant speed for long periods of time.

Table (7) Shows the results of water tests treated with active carbon

\begin{tabular}{|c|c|c|}
\hline NO & Test & Result \\
\hline 1 & TSS (ppm) & 5.6 \\
\hline 2 & TDS (ppm) & 4872.6 \\
\hline 3 & $\mathrm{Na}^{+}(\mathrm{ppm})$ & 263.5 \\
\hline 4 & $\mathrm{~K}^{+}(\mathrm{ppm})$ & 2.75 \\
\hline 5 & $\mathrm{SO}_{4}^{-2}(\mathrm{ppm})$ & 531 \\
\hline 6 & $\mathrm{PH}$ & 6.1 \\
\hline 7 & Conductivity $\mu \mathrm{s} / \mathrm{CM}$ & 1115 \\
\hline 8 & Refractive Index (RI) & 1.33377 \\
\hline 9 & Density@15.6 C $\mathrm{C}$ g/cm & 0.99371 \\
\hline 10 & SP.GR@15.6 C & 0.9947 \\
\hline 11 & Turbidity (NTU) & 3.40 \\
\hline 12 & Chloride $\mathrm{Cl}^{-}$(ppm) & 849.6 \\
\hline 13 & $\mathrm{Mg}^{+}(\mathrm{ppm})$ & 101.8 \\
\hline 14 & $\mathrm{~S}^{-2}$ & 2 \\
\hline
\end{tabular}

The obtained results show that the concentration of many substances has been significantly reduced as a result of treatment with active carbon water. The concentration of chloride, sulphate, hydrogen sulphide and magnesium has decreased, as has the value of TDS and TSS.

\section{Treatment of industrial water using CNT}

After studying the effectiveness of active carbon on the removal of organic pollutants, the substance (MCNT).

Multi wall carbon Nano tube where the final system and the mobilization of the column was used with CNT material, in order to accelerate the flow through the CNT material and ensure that the material is not overcrowded due to runoff pressure and disposal of dead areas passing through the liquid without prejudice to the material was added equal percentages of glass granules to CNT, Table (8) shows the specifications of the CNT used. Several tests were carried out on CNT in order to know its properties and composition. 
Table (8) shows the specifications of Multi-walled carbon nanotubes (MCNT)

\begin{tabular}{|c|c|c|}
\hline NO & Test & Result \\
\hline 1 & Purity & $>99 \mathrm{wt} \%$ \\
\hline \hline 2 & Length & $1-12 \mathrm{~nm}$ \\
\hline 3 & Ash & $0 \mathrm{wt} \%$ \\
\hline 4 & SSA & $>233 \mathrm{~m}^{2} / \mathrm{g}$ \\
\hline \hline 5 & Process gas & Argon \\
\hline \hline 6 & Primary functionality & None \\
\hline 7 & Other functionality & Atmospheric gas \\
\hline 8 & EC & $>10^{2} \mathrm{~s} / \mathrm{cm}$ \\
\hline \hline 9 & Form Supplied & Dry powder \\
\hline 10 & OD & $13-18 \mathrm{~nm}$ \\
\hline
\end{tabular}

\section{$\underline{\text { X-Ray Diffract meter }}$}

The carbon nanotube model is examined by X-Ray Diffract meter and is used to diagnose the composition properties of solids only and is not used to examine liquids and wet materials. Figure (20) shows an XRD diagram of CNT.

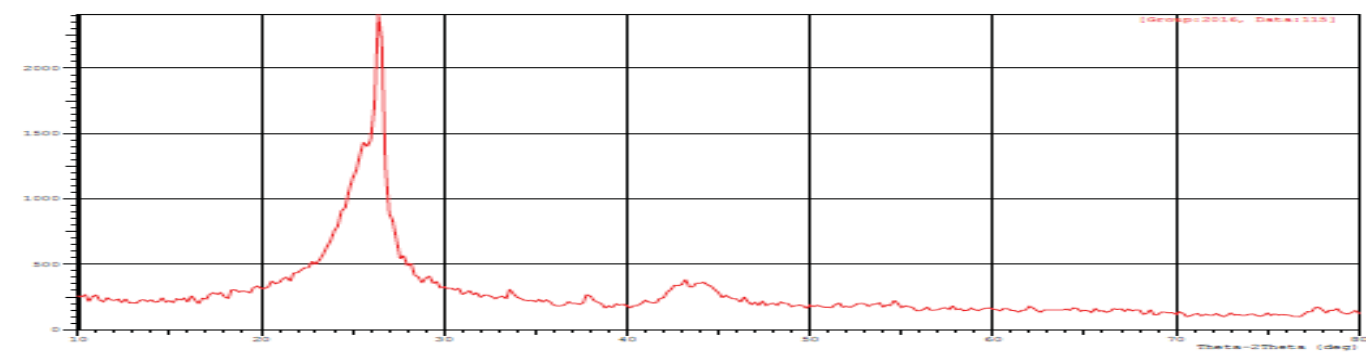

Fig. (20) Shows the CNT examination with an X-Ray Diffract meter

\section{SEM examination}

The sample of the activated carbon is measured in different dimensions $(10 \mu \mathrm{m}, 5 \mu \mathrm{m}, 2 \mu \mathrm{m})$ respectively shows in figure (21) A, B and C. 


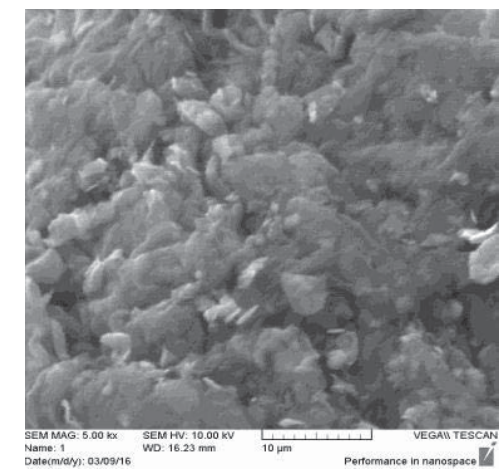

Fig. (21A) shows the activated carbon image of the electron microscopy microscope and after it $10 \mu \mathrm{m}$

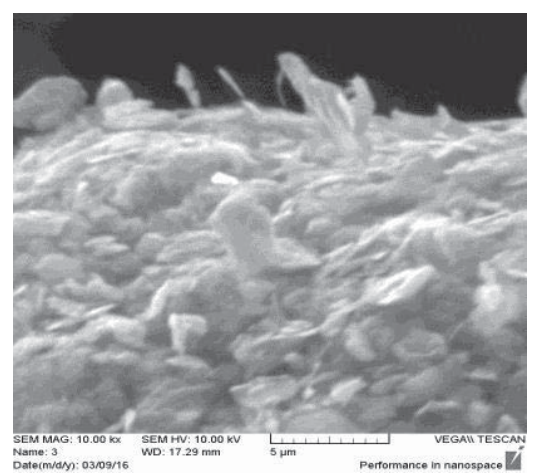

Fig. (21B) shows the activated carbon image of the electron microscopy microscope and after it $5 \mu \mathrm{m}$

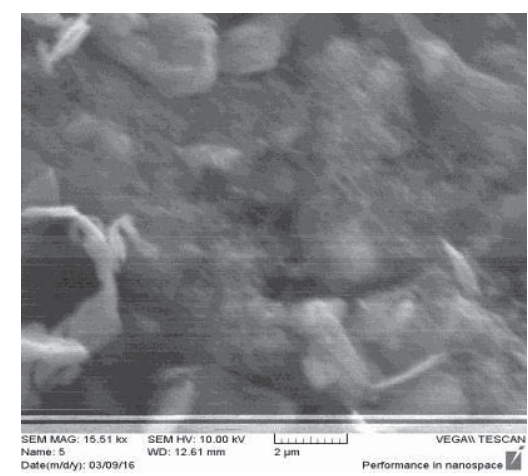

Fig. (21C) shows the activated carbon image of the scanner electron microscope and then $2 \mu \mathrm{m}$

\section{$\underline{\text { Inspection of FTIR }}$}

The FTIR test was conducted to determine the active aggregates present in a CNT model and Figure (22) showing the FTIR diagram of CNT.

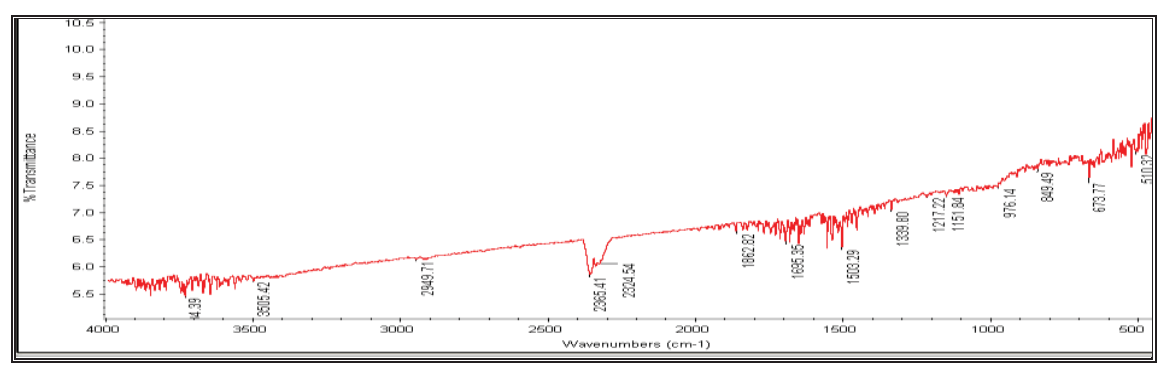

Fig. (22) Shows the FTIR diagram of CNT

The results of the TOC test on the water outside the system for different periods of time were shown in Table (9).

Table (9) shows the results of the TOC test on the water outside the system for different periods of time. (10) shows the results of other laboratory tests carried out on the outside water 
Table (9) Shows the results of the TOC test on water outside the system using CNT

\begin{tabular}{|r|c|c||}
\hline NO & Time $(\mathrm{min})$ & TOC $(\mathbf{p p m})$ \\
\hline \hline 1 & Before treatment & 13.27 \\
\hline 2 & waste & 15.13 \\
\hline 3 & After flotation & 11.95 \\
\hline 4 & 0 & NIL \\
\hline 5 & 15 & NIL \\
\hline 6 & 30 & NIL \\
\hline 7 & 60 & NIL \\
\hline \hline 8 & 90 & NIL \\
\hline 9 & 120 & NIL \\
\hline \hline 10 & 150 & NIL \\
\hline \hline 11 & 210 & NIL \\
\hline 12 & 270 & NIL \\
\hline 13 & 330 & NIL \\
\hline
\end{tabular}

Table (10) Shows the results of CNT treated water tests

\begin{tabular}{|c|c|c|}
\hline NO & Test & Result \\
\hline 1 & TSS (ppm) & 4.1 \\
\hline 2 & TDS (ppm) & 219.4 \\
\hline 3 & $\mathrm{Na}^{+}(\mathrm{ppm})$ & 221.3 \\
\hline 4 & $\mathrm{~K}^{+}(\mathrm{ppm})$ & 0.97 \\
\hline$\overline{5}$ & $\mathrm{So}_{4}{ }^{-2}$ (ppm) & 387 \\
\hline$\overline{66}$ & $\overline{\mathrm{PH}}$ & 7.5 \\
\hline 7 & Conductivity & 1078 \\
\hline 8 & RI & 1.33357 \\
\hline 9 & Density@15.6 C & 1.00476 \\
\hline 10 & SP.GR@15.6 C & 1.0058 \\
\hline 11 & Turbidity (NTU) & NIL \\
\hline 12 & Chloride $\mathrm{Cl}^{-}(\mathrm{ppm})$ & 790.4 \\
\hline 13 & $\mathrm{Mg}^{+}(\mathrm{ppm})$ & 91.3 \\
\hline 14 & $\mathrm{~S}^{-2}$ & Nil \\
\hline
\end{tabular}

CNT has been shown to have a higher efficiency in the removal of organic matter in the same variables, so the flow velocity has been increased in order to determine the efficiency of the material in high flow velocity and table (11). 
Tble (11) Results of the (TOC) test of treated water using CNT at different speeds

\begin{tabular}{|c||c||c|}
\hline NO. & Flow rate $\mathbf{( m l} / \mathbf{m i n})$ & TOC $(\mathbf{p p m})$ \\
\hline \hline 1 & 10 & Nil \\
\hline 2 & 20 & Nil \\
\hline 3 & 30 & Nil \\
\hline \hline 4 & 40 & Nil \\
\hline \hline 5 & 50 & Nil \\
\hline \hline 6 & 60 & Nil \\
\hline
\end{tabular}

\section{Column Capacity}

The CNT materials showed their high ability to remove organic matter from industrial water and for long periods of time. In order to know the capacity of the column (the material's ability to absorb the largest amount of material) we attended a model of ordinary water and we added ( $0.5 \mathrm{~g}$ of Bromocresol green) $1000 \mathrm{ml}$ distilled water ie $500 \mathrm{ppm}$ prepared. The concentration of water recorded on the system was measured at $10 \mathrm{ml} / \mathrm{min}$. We examined the concentration of bromocresol green in the UV-VIS system on the water outside the system as evidence of organic matter concentration (instead of TOC). Table (12) Water is prepared laboratory over time by passing on the system

Table (12) Results of laboratory water treatment

\begin{tabular}{|c||c||c||}
\hline NO & Time (min) & Concentration $\mathbf{( p p m ) ~}$ \\
\hline \hline 1 & 30 & Nil \\
\hline 2 & 60 & Nil \\
\hline 3 & 90 & Nil \\
\hline 4 & 120 & Nil \\
\hline 5 & 150 & Nil \\
\hline 6 & 180 & Nil \\
\hline 7 & 210 & 0.48 \\
\hline 8 & 240 & 0.83 \\
\hline
\end{tabular}

Note from Table (12) that Bromcresol started to appear in the water exiting the system after 180 minutes, after 1,800 $\mathrm{ml}$ of prepared water, ie CNT absorbed $900 \mathrm{ppm}$ of organic matter. The weight of the CNT material in the column is $5 \mathrm{~g}$, ie the column capacity is $900 \mathrm{mg} / \mathrm{g}$

\section{Reactivation of Carbon Nano tube:}

Reactivation of CNT is one of the important steps to reuse it as it was reactivated in two phases The first phase (Pack wash): Passing hot water to the system at $90{ }^{\circ} \mathrm{C}$ as the first step to extract organic matter from CNT. The sample was examined and it was noted that it contained $92 \mathrm{ppm}$ of 
organic matter, i.e., higher than the concentration of organic matter in the industrial water entering about seven times.

Phase II (Heating) :The activation of the CNT material was completed using high temperature heating. The column containing the CNT was wrapped with a heating coil and the column was connected to a source of hot nitrogen gas to expel the oxygen to avoid oxidation of the material during heating. Pass the hot nitrogen gas on the column and heat the column to $380{ }^{\circ} \mathrm{C}$ for 20 minutes until no vapors are visible from the column. Figure (23) illustrates the second step of reactivation using heating. In addition, a sample of CNT was taken and examined with FTIR to detect changes. No other effective group was observed compared with the FTIR test prior to use. Figure (24) illustrates the FTIR test pattern of CNT after reactivation. The work was done with the material again after the reactivation where the water was prepared laboratory (dissolved bromocrizol) where the same amount of previous organic materials on the column and the substance was the same efficiency in the removal of organic matter and the same periods of time
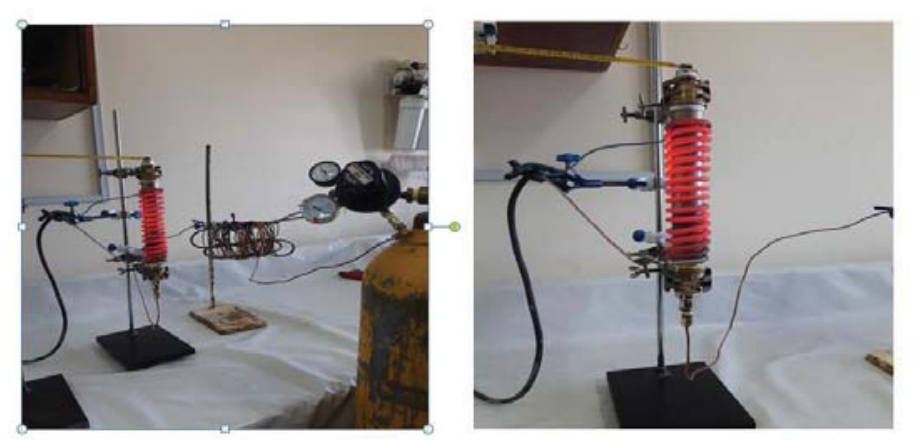

Figure (23) Shows the reactivation step using heating and nitrogen gas discharge

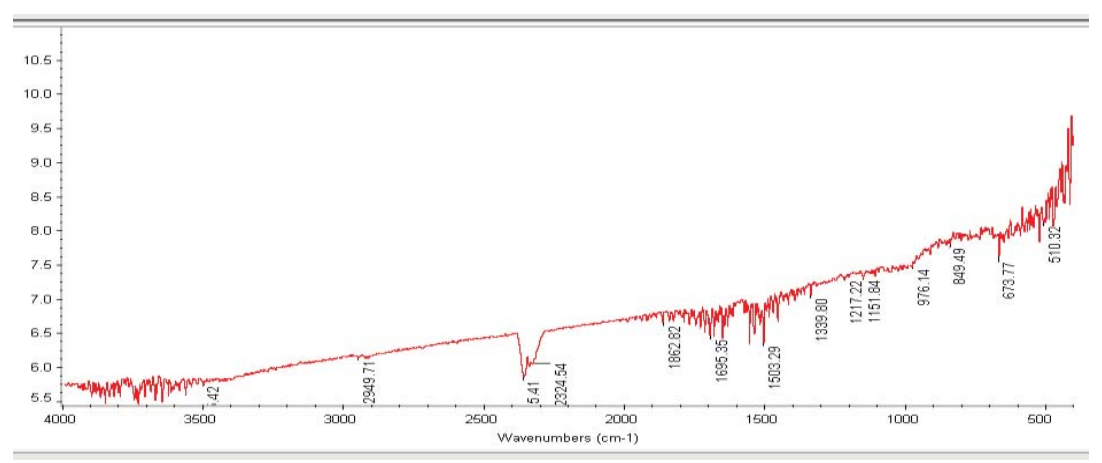

Figure (24) Shows the FTIR test of CNT after reactivation 


\section{Conclusions:}

Waste water (contaminated water) is defined as any water contaminated with organic or bacterial contaminants or as fine containers whether from an industrial source or sewage. Industrial wastewater treatment includes primary treatment, secondary treatment and triple treatment: to remove the remaining hydrocarbon from the floating organic matter (oil), followed by the process of removing hydrocarbons dissolved in water or emulsion. The nanotubes, carbon nanotubes (CNTs) and activated carbon powder were used here after modulating or developing the flow method through the systems containing these substances. The most important conclusions can be summarized as follows:

1. Active carbon solubility removes organic matter from industrial water and maintains its concentration to lower levels where active coal is at low flow velocity.

2. Nano materials are characterized by very high properties such as the size of the surface area and the height of the ionic property and the ease of modification of its surfaces chemically.

3. Carbon nanotubes have been shown to have high properties of adsorption of water-soluble substances and hydrocarbons at high flow velocity.

4. The use of nanoparticles directly in the systems is impossible because the nanoparticles will be a barrier to prevent the passage of water through them. In order to avoid this problem, the nanoparticle was placed in a cylindrical bag and then the bag was made in a snail to facilitate the passage of water through it. The water will be applied through the outer part of the bag containing the nuclear material, so the contact area will be low and thus the effectiveness will be low. This was the most successful solution to this problem. The development of the work was by mixing volumes of nanoparticles into certain sizes of glass beads. Flux Direct water research through Nano materials where the conclusion was that the effectiveness of Nano materials was very large in the removal of total organic compounds (TOC) and by removal of up to $100 \%$.

\section{High capacitance of CNT to absorb organic matter as well as some element ions}

6. The possibility of re-efficiency of Nano materials and their removal from hydrocarbons absorbed by hot pure nitrogen and heating the outer wall of the metal container containing nanoparticles and the pure nitrogen stream pressure to control the carbon nanotubes of oxidation in the case of oxygen. 


\section{No.19}

7. The use of sand filter is very important for the durable use of Nano materials for as long as possible, as it prevents the passage of linings and suspended materials from industrial water to the system containing Nano materials

8. The plucking and scraping system is necessary to remove a percentage of the suspended material and the insoluble organic matter.

9. It is also noted that the weight of machines used and the small size and increase the surface area of materials used in this technology, which increases the speed of interactions and increases production and reduce costs. 


\section{References}

1. AM T. H. ABOU KANA, MOHAMMED RADI2\& MAHER Z ELSABEE, "WASTEWATER TREATMENT WITH CHITOSAN NANO-PARTICLES", International Journal of Nanotechnology and Application (IJNA), ISSN 2277-4777 ,Vol. 3, Issue 2, Jun 2013, 39-50

2. HONGJIE DAI, Carbon Nanotubes: Synthesis, Integration and Properties," Acc. Chem. Res. Issue 35, 2002, pp 1035-1044

3. Bahareh Asadollahi Esfahani, Banafsheh Asadollahi Esfahani, Mina Shams Koupaei, Seyyedeh Zahra Ghasemi, INDUSTRIAL WASTE WATER TREATMENT BY MEMBRANE SYSTEMS," Indian Journal of Fundamental and Applied Life Sciences ,ISSN. 2231,2014, pp. 1168-1177

4. Koivunen, J., Siitonen, A., Heinonen- Tanski, H.,"Elimination of enteric bacteria in biologicalchemical wastewater treatment and tertiary filtration units," Water Res., Issue 37,2003, pp 690698.

5. Nordberg G. F., Flower B., Nordberg M., and Friberg L., " Handbook on the Toxicology of Metals", USA, 3rd edition, 2007.

6. Y. H. Li, Y. M. Zhao, W. B. Hu, I. Ahmad, Y. Q. Zhu, X. J. Peng, Z. K. Luan" Carbon nanotubes - the promising adsorbent in wastewater Treatment' Journal of Physics, Issue 61, (2007), pp 698702

7. Prabhakar R. Bandaru, "Electrical Properties and Applications of Carbon Nanotube Structures,", Journal of Nanoscience and Nanotechnology Vol.7, 2007, pp1-29

8. Ibrahim M., Juma N., "Development a method for production of CNTs", Journal of Baghdad Engineering, College of Engineering, accepted 2012.

9. Clesceri, L. S., Greenberg A. E., Eaton A. D.," Standard methods for the examination of water and wastewater", 20th ed. American public health association, Washington.1998.

10. Sonune, A., Ghate, R, Developments in wastewater treatment methods, Desalination,'Issue 167,2004, pp 55-63.

11. Galambos II, Molina J. M., Jaray P., Vatai G., Bekassy-Molnar E., High organic content industrial wastewater treatment by membrane filtration". Desalination Issue 162,2004,pp 117120. 